\title{
Elevated Hepatic Glucose Production in Children with Cystic Fibrosis
}

\author{
C. LAWRENCE KIEN, CRAIG A. HORSWILL, WILLIAM B. ZIPF, KAREN S. MCCOY, AND \\ THOMAS O'DORISIO \\ Department of Pediatrics, The Ohio State University College of Medicine and Children's Hospital, \\ Columbia, Ohio 43205
}

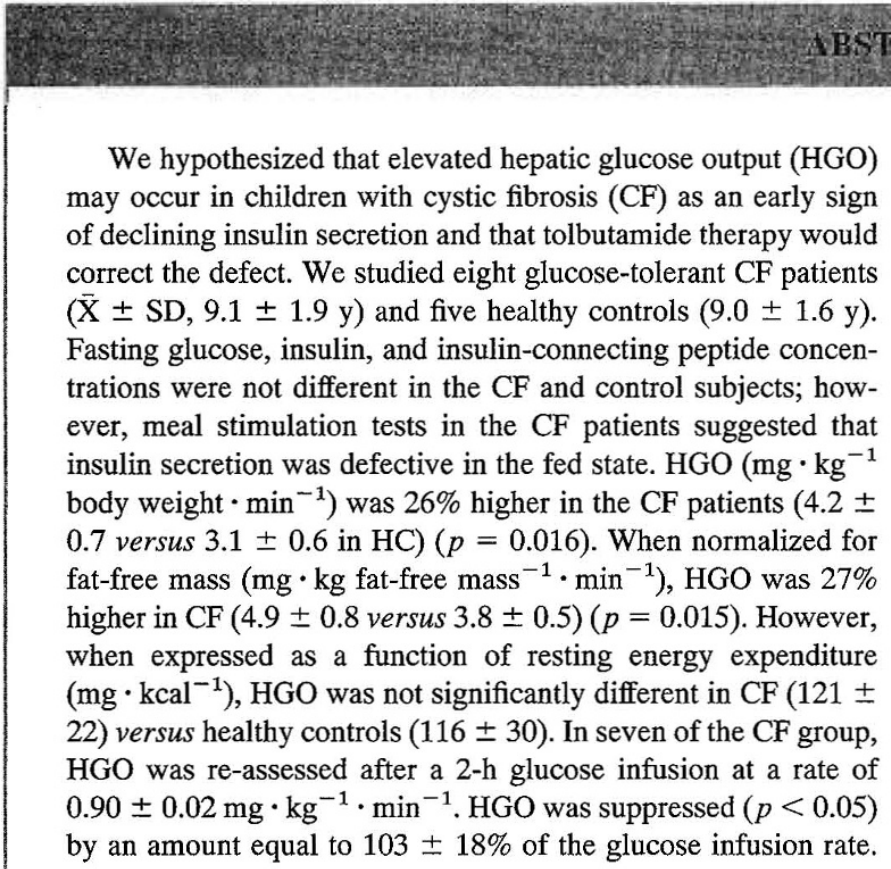

Many patients with CF have secondary complications of glucose intolerance, the incidence of which appears to increase with age (1-4). In a retrospective study of clinical data, Lanng et al. (5) compared CF patients who developed diabetes mellitus with control CF patients during the previous 6-y period. Those who had developed diabetes demonstrated impaired weight gain (and lower body mass index), worsening pulmonary function, and impaired exocrine pancreatic function from 1 to $4.5 \mathrm{y}$ before the diagnosis of diabetes.

We (6) previously showed that tolbutamide therapy in nondiabetic children with CF is associated with improved growth and accretion of fat-free mass in comparison to a baseline observation period. Subsequently, we found that feeding did not suppress whole body proteolysis in children with $\mathrm{CF}$, suggesting that impaired insulin secretion or insulin action

Received July 1, 1994; accepted December 20, 1994.

Correspondence and reprint requests: C. Lawrence Kien, M.D., Ph.D., Room W209, Children's Hospital, 700 Children's Drive, Columbus, OH 43205.

Supported in part by the Cystic Fibrosis Foundation, Children's Hospital Research Foundation, and NIH Grant MO1 RR00034 (General Clinical Research Center).
Finally, in five CF patients, HGO was re-measured after 2 wk of oral therapy with tolbutamide $(750 \mathrm{mg} / \mathrm{d})$. Tolbutamide did not affect HGO (fasting or during the glucose infusion). In conclusion, fasting HGO was elevated in the CF patients in proportion to energy expenditure. (Pediatr Res 37: 600-605, 1995)

CF, cystic fibrosis
C peptide, insulin-connecting peptide
$\mathrm{D}_{2} \mathrm{O}$, deuterium oxide
F DG, the rate of administration of glucose tracer
GCRC, NIH General Clinical Research Center
HGO, hepatic glucose output

IE DG, isotopic enrichment of glucose produced by deuterated glucose tracer

Ra DG, rate of appearance of glucose measured using deuterated glucose

$\mathrm{VCO}_{2}$, net rate of excretion of $\mathrm{CO}_{2}$ (equated to rate of $\mathrm{CO}_{2}$ production) might limit accretion of protein in this patient population (7). We speculated that impaired nutritional status could limit host defense and pulmonary function resulting in increased infection and worsening prognosis.

As part of a therapeutic trial, we examined the effect of tolbutamide on HGO and its suppressibility by i.v. glucose infusion and also compared fasting $\mathrm{HGO}$ in the patients with that in healthy control children. This report describes the results of this study.

\section{METHODS}

Subjects. Eight, nondiabetic, prepubertal, CF patients requiring oral pancreatic enzyme supplementation were recruited for this study (Table 1). In addition, we recruited five healthy controls. To participate, subjects had to be free of overt infection, afebrile, and off antibiotics for a minimum of 10 days before being studied. In addition, the CF patients had to be glucose-tolerant as evidenced by plasma glucose concentrations $2 \mathrm{~h}$ after a standard meal (vide infra) (6). The procedures were explained to the subjects and their parents, and informed 
Table 1. Physical characteristics of the CF patients

\begin{tabular}{|c|c|c|c|c|c|c|c|}
\hline Subject no. & Sex & TS & Age (y) & Height $(\mathrm{cm})$ & Weight (kg) & IBW (\%) & CF score \\
\hline \multicolumn{8}{|l|}{ CF patients } \\
\hline $2029 *$ & $\mathrm{~F}$ & 1 & 10.5 & 132.9 & 33.6 & 116 & 89 \\
\hline 2012 & M & 1 & 9.5 & 123.3 & 24.2 & 103 & 92 \\
\hline 2031 & M & 1 & 11.4 & 144.0 & 28.1 & 78 & 76 \\
\hline 2036 & M & 1 & 7.3 & 118.0 & 20.5 & 95 & 95 \\
\hline 2035 & M & 1 & 8.0 & 120.4 & 20.2 & 92 & 73 \\
\hline 2038 & M & 1 & 11.3 & 140.1 & 31.3 & 94 & 79 \\
\hline 2039 & M & 1 & 8.5 & 130.5 & 30.6 & 113 & 91 \\
\hline 2041 & M & 1 & 6.4 & 112.7 & 19.3 & 99 & N/A \\
\hline Mean $\pm S D$ & & & $9.1 \pm 1.9 \dagger$ & $127.8 \pm 11.5 \dagger$ & $26.0 \pm 5.6 \dagger$ & $99 \pm 12 \dagger$ & \\
\hline \multicolumn{8}{|l|}{ Healthy controls } \\
\hline 2030 & $\mathrm{~F}$ & 1 & 11.1 & 139.9 & 31.9 & 94 & N/A \\
\hline 2032 & M & 1 & 6.7 & 125.7 & 25.4 & 102 & N/A \\
\hline 2033 & $\mathrm{~F}$ & 1 & 8.8 & 132.7 & 36.8 & 127 & N/A \\
\hline 2034 & M & 1 & 9.6 & 133.2 & 28.0 & 97 & N/A \\
\hline 2037 & $\mathrm{~F}$ & 1 & 9.0 & 146.5 & 39.2 & 103 & N/A \\
\hline Mean $\pm \mathrm{SD}$ & & & $9.0 \pm 1.6 \dagger$ & $135.6 \pm 7.9 \dagger$ & $32.3 \pm 5.8 \dagger$ & $105 \pm 13 \dagger$ & \\
\hline
\end{tabular}

Abbreviations used: TS, Tanner stage (8) used to assess maturation; percent IBW, $100 \cdot$ (weight $\div$ median weight for height age); CF score, NIH criteria for clinical status of cystic fibrosis; N/A, not available or not applicable.

* Subject no. 2029 was receiving systemic steroid therapy (prednisone $5 \mathrm{mg}$ p.o. every day) at the time of each study.

$\dagger$ There were no significant differences between groups in age, height, weight, or percent IBW.

consent was obtained before participation in the study. The study was approved by the institutions' committees for research on human subjects.

To determine the degree to which HGO in the fasting state was abnormal in the CF patients, we also assessed glucose turnover in five healthy, prepubertal children (8).

Experimental design. Four days before the glucose tracer study, total body water was estimated using the procedure noted below.

As part of our overall study which included measurements of leucine oxidation in the fed and fasted states, subjects were admitted to the General Clinical Research Center (GCRC) for $4 \mathrm{~d}$. During the first $3 \mathrm{~d}$ of admission, subjects were provided a diet that matched the energy intake of the typical diet based on 4-d diet records kept by the subjects. Subjects began fasting at $2100 \mathrm{~h}$ on $\mathrm{d} 3$ and continued to fast until $1400 \mathrm{~h}$ on $\mathrm{d} 4$. During the period, $0900-0950 \mathrm{~h}$ on $\mathrm{d} 4$, the $\mathrm{VCO}_{2}$ was measured using the Douglas bag technique (described below). A catheter for blood drawing was inserted into a peripheral vein of an upper extremity on $\mathrm{d} 3$; after warming the vein, a blood sample was drawn from this catheter at $0950 \mathrm{~h}$ on $\mathrm{d} 4$ for assessment of background enrichment of plasma glucose. A second catheter in the opposite arm was also inserted on $\mathrm{d} 3$ and used for isotope and glucose infusion. Beginning at 1000 $\mathrm{h}$ on $\mathrm{d} 4$, subjects received a prime constant infusion of [6,6- $\left.\mathrm{d}_{2}\right]$-glucose (99\%, MSD Isotope; Quebec, Canada; prime: 18 $\mu \mathrm{mol} \cdot \mathrm{kg}$ body weight ${ }^{-1}$; infusion: $0.22 \mu \mathrm{mol} \cdot \mathrm{kg}^{-1} \cdot \min ^{-1}$ or $0.04 \mathrm{mg} \cdot \mathrm{kg}^{-1} \cdot \mathrm{min}^{-1}$ ). After $80 \mathrm{~min}$ of infusion, four blood samples were drawn at 10 -min intervals. Samples were centrifuged, and plasma was stored at $-80^{\circ} \mathrm{C}$ until analysis of the enrichment of plasma glucose. In addition, plasma samples obtained during the last $40 \mathrm{~min}$ of the fasting tracer infusion were pooled and analyzed for glucose, insulin, and $\mathrm{C}$ peptide concentrations.

At the end of $2 \mathrm{~h}$, in the CF patients only, while the deuterated glucose infusion continued, an i.v. infusion of unla- beled glucose at an approximate rate of $1.0 \mathrm{mg} \cdot \mathrm{kg}^{-1} \cdot \mathrm{min}^{-1}(5.6$ $\mu \mathrm{mol} \cdot \mathrm{kg} \cdot \min ^{-1}$ ) was administered to determine the suppressibility of the hepatic glucose output by glucose (9). Blood samples were collected during the period 80-120 min of the dual infusion, again at 10 -min intervals.

After the completion of these fasting studies, the subjects were allowed to eat, and then they were discharged from the GCRC. However, five of the CF patients then began daily therapy with tolbutamide ( $750 \mathrm{mg} /$ day) for $2 \mathrm{wk}$ after which the tracer studies were repeated according to the protocol just described.

Healthy controls were admitted to the GCRC overnight and studied the next morning at $1000 \mathrm{~h}$, after a $13-\mathrm{h}$ fast.

Estimation of $\mathbf{H G O}$. The Ra DG was calculated as follows (10):

$$
\mathrm{Ra} D G=(F \mathrm{DG}) /(\mathrm{IE} D G)
$$

where F DG is the rate of administration of $\left[6,6-\mathrm{d}_{2}\right]$-glucose (molar units, corrected for enrichment) and IE DG is the isotopic enrichment of plasma glucose (expressed as fractional abundance, moles fraction excess). For the data reported here, the rate of appearance of glucose was not corrected for the infusion rate of tracer, because there is evidence that even tracer doses of glucose will suppress endogenous glucose production proportionately (11). However, since there is controversy about the correct approach, we also repeated our calculations using such a correction (11). There was a slightly greater relative increase in $\mathrm{HGO}$ in the CF patients using this correction (also see "Results"), but the data describing the effects of the glucose infusions and tolbutamide therapy were virtually identical using this approach. HGO was equated to $\mathrm{Ra}$ DG in the fasting state. During the glucose infusion, HGO was calculated by subtracting the rate of glucose infusion from $\mathrm{Ra}$ DG.

The HGO data in the resting, baseline state in the two groups were compared when expressed per unit body weight and per 
unit fat-free mass, to correct for differences in body composition between the two groups. Several (12-15) but not all (16) studies suggest that resting energy expenditure is abnormally elevated in CF patients. Because energy expenditure per unit cell then may be greater in children with CF compared with healthy children, we also compared fasting $\mathrm{HGO}$ data in the two groups as a function of resting energy expenditure estimated from the $\mathrm{VCO}_{2}$.

$G C / M S$. The enrichment of plasma glucose (IE DG) and the tracer was analyzed using the pentacetate derivative and electron impact, gas chromatography/mass spectrometry GC/MS (17). The following ions were monitored: $200(\mathrm{M}), 201(\mathrm{M}+$ $1)$, and $202(M+2)$. We monitored the 201 ion to correct the 202 enrichment for excess enrichment produced by recycled 203 ion (i.e. the original deuterated tracer containing a naturally abundant ${ }^{13} \mathrm{C}$ atom) (18).

Measurement of body composition. Fat-free mass and percent of body fat were estimated from measurements of total body water determined using either ${ }^{18} \mathrm{O}$-water or $\mathrm{D}_{2} \mathrm{O}$. After collecting a baseline urine sample (and emptying the bladder), subjects ingested either $0.3 \mathrm{~g}^{18} \mathrm{O}$-water $\cdot \mathrm{kg}$ body weight ${ }^{-1}$ (or about $15 \mathrm{mmol} \cdot \mathrm{kg}$ body weight $\left.{ }^{-1}\right)(11.2 \%$, MSD Isotope, Ontario, Canada) or $0.04 \mathrm{~g} \mathrm{D}_{2} \mathrm{O} \cdot \mathrm{kg}^{-1}$ body weight (or about $2 \mathrm{mmol} \cdot \mathrm{kg}$ weight $^{-1}$ ) $(99 \%$, MSD Isotope, Ontario, Canada). Urine samples were collected 3 and $4 \mathrm{~h}$ after tracer ingestion; the 4-h sample was used to determine the equilibrium enrichment of the body water. To determine enrichment of ${ }^{18} \mathrm{O}$ in the urine, samples were equilibrated with $\mathrm{CO}_{2}$ for $72 \mathrm{~h}$, and the gas sample was then cryogenically purified and then analyzed by gas isotope ratio mass spectrometry (Delta E, Finnigan MAT, Bremen, Germany) (17). $\mathrm{D}_{2} \mathrm{O}$ enrichment was determined also by gas isotope ratio mass spectrometry using the zinc reduction method (19). Total body water was calculated using the deuterium or ${ }^{18} \mathrm{O}$ labeled isotopes after correction for isotopic fractionation $(20,21)$. An adjustment was made in the calculations for the fact that the $\mathrm{D}_{2} \mathrm{O}$ space is about $3 \%$ larger than the $\mathrm{H}_{2}{ }^{18} \mathrm{O}$ space (17). Using an estimate of the hydration of fat-free mass that was appropriate for sex, ethnicity, and maturation level (22), total body water was converted to fatfree weight.

Measurement of the $\mathrm{VCO}_{2}$ and estimation of energy expenditure. Using a face mouthpiece, 2-way non-re-breathing valve, and Douglas bags, expired air was collected for two, 6-min periods in the fed and fasted state. Subjects, at rest and in a reclining position, were briefly accustomed to the apparatus before actually collecting expired air samples. A $60-\mathrm{ml}$ aliquot was drawn from each bag and set aside for subsequent analysis of the fractional concentration of $\mathrm{CO}_{2}$, measured with a Beckman Industrial $\mathrm{CO}_{2}$ analyzer (Beckman Instruments, Fullerton, CA). The volume of the timed collection was measured with a Rayfield gas meter (Rayfield System, Chicago, IL), which had been validated against a Tissot spirometer. Assuming a room air $\mathrm{CO}_{2}$ concentration of $0.03 \%, \mathrm{VcO}_{2}$ was then calculated. Energy expenditure was estimated by standard equations (23) assuming a respiratory quotient of 0.834 (12).

Measurement of plasma and tracer concentrations of glucose, plasma concentrations of insulin and $C$ peptide, and meal stimulation test. Glucose concentration was measured using a YSI Glucose Analyzer (model 27, Yellow Springs Instrument Co., Yellow Springs, $\mathrm{OH}$ ). Plasma insulin and $\mathrm{C}$ peptide were measured by radioimmunoassay using previously described methodology (24). The assay sensitivity for insulin was approximately $2.5 \mu \mathrm{U} \cdot \mathrm{ml}^{-1}$ (or $17.9 \mathrm{pmol} \cdot \mathrm{L}^{-1}$ ) and the assay sensitivity for $\mathrm{C}$ peptide was about $0.1 \mathrm{ng} \cdot \mathrm{ml}^{-1}$ (or $\left.0.033 \cdot \mathrm{nmol} \cdot \mathrm{L}^{-1}\right)$.

In the CF patients only, a meal stimulation test was conducted as previously described (6) as part of our initial screening of the subjects. The data were compared with laboratory control data from previous studies in nine healthy, prepubertal children not involved with the tracer studies.

Statistical design. Data are presented as mean \pm SD. A two-sample $t$ test was used to determine whether HGO differed between CF patients and healthy controls. A paired $t$ test was used to evaluate the suppressibility of HGO when unlabeled glucose was infused and to assess the effect of tolbutamide on HGO. A probability level of 0.05 was selected for statistical significance.

\section{RESULTS}

Individual CF patient characteristics are presented in Table 1. The mean ages of the CF patients and healthy controls were respectively $9.1 \pm 1.9$ y and $9.0 \pm 1.6$ y. Fasting glucose concentration $\left(\mathrm{mg} \cdot \mathrm{dl}^{-1}\right.$ or $\mathrm{mmol} \cdot \mathrm{L}^{-1}$ ) in the CF patients (84 \pm 19 or $4.7 \pm 1.1$ ) was not statistically different from controls $(81 \pm 7$ or $4.5 \pm 0.4)$.

Insulin and $\mathrm{C}$ peptide concentrations during the last $30 \mathrm{~min}$ of the fasted tracer study (before tolbutamide therapy) were, respectively, $2.2 \pm 2.0 \mu \mathrm{U} \cdot \mathrm{ml}^{-1}\left(15.8 \pm 14.4 \mathrm{pmol} \cdot \mathrm{L}^{-1}\right)$ and $0.8 \pm 0.8 \mathrm{ng} \cdot \mathrm{ml}^{-1}\left(0.26 \pm 0.26 \mathrm{nmol} \cdot \mathrm{L}^{-1}\right)$ in the CF patients $(n=8)$ and $2.6 \pm 1.2 \mu \mathrm{U} \cdot \mathrm{ml}^{-1}(18.7 \pm 8.6$ $\left.\mathrm{pmol} \cdot \mathrm{L}^{-1}\right)$ and $0.9 \pm 0.4 \mathrm{ng} \cdot \mathrm{ml}^{-1}\left(0.30 \pm 0.13 \mathrm{nmol} \cdot \mathrm{L}^{-1}\right)$ in the controls $(p>0.05$ for both). There also were no differences in the means of the individual ratios for insulin/C peptide between the CF patients $(3.4 \pm 2.7)$ and controls (3.1 $\pm 1.5)$ or in the means for the fasting glucose/insulin concentration ratio between CF patients $(0.025 \pm 0.015)$ and controls $(0.032 \pm 0.013)$.

During the meal stimulation test, the mean area under the curve for glucose was not significantly different from that derived from the previously studied, laboratory controls $\left(15650 \pm 1494\right.$ versus $\left.15430 \pm 1599 \mathrm{mg} \cdot \mathrm{dL}^{-1} \cdot \min \right)(869$ \pm 83 versus $856 \pm 89 \mathrm{mmol} \cdot \mathrm{L}^{-1}$ ). The mean area under the curve for insulin was $40 \%$ of the control value $(1099 \pm 534$ versus $\left.2734 \pm 1091 \mu \mathrm{U} \cdot \mathrm{ml}^{-1} \cdot \min \right)(7885 \pm 3831$ versus $\left.19616 \pm 7828 \mathrm{pmol} \cdot \mathrm{L}^{-1} \cdot \min \right)(p=0.002)$; the value in all CF patients was below the control mean, and in six of seven was greater than 1 SD below the mean (Fig. 1). The mean area under the curve for $\mathrm{C}$ peptide was $60 \%$ of the control mean $(p>0.05)$, and in four of seven was greater than $1 \mathrm{SD}$ below the control mean (Fig. 2).

HGO $\left(\mathrm{mg} \cdot \mathrm{kg}\right.$ body weight ${ }^{-1} \cdot \mathrm{min}^{-1}$ or $\mu \mathrm{mol} \cdot \mathrm{kg}$ body weight $\left.{ }^{-1} \cdot \min ^{-1}\right)$ was $26 \%$ greater in CF patients $(4.2 \pm 0.7$ or $23.3 \pm 3.8)$ than in healthy controls $(3.1 \pm 0.6$ or $17.2 \pm$ 3.3) $(p<0.05)$ (Fig. 3); factoring in the tracer infusion in the 


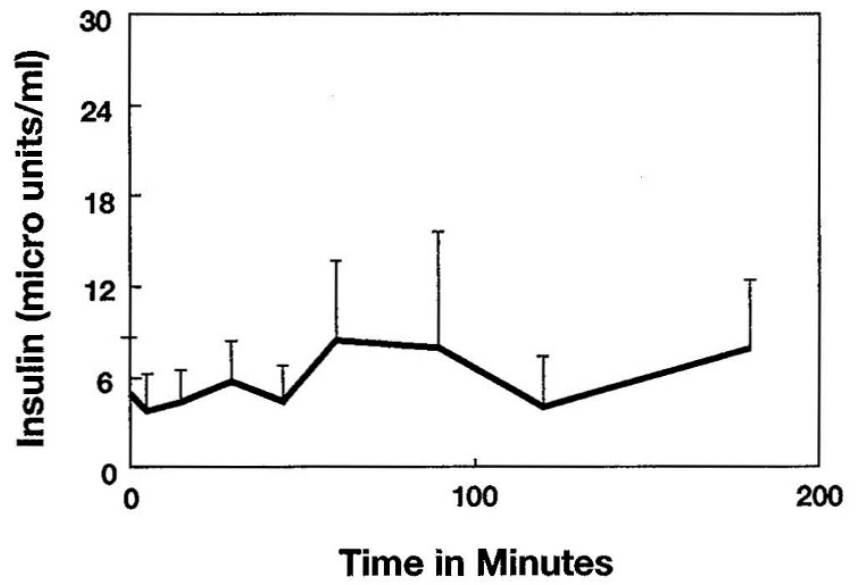

Figure 1. Insulin response in $\mathrm{CF}$ patients during meal stimulation test $\left(\mu \mathrm{U} \cdot \mathrm{ml}^{-1}\right.$ ) (equal to $\left.7.175 \mathrm{pmol} \cdot \mathrm{L}^{-1}\right)(\overline{\mathrm{X}} \pm \mathrm{SD}$ ).

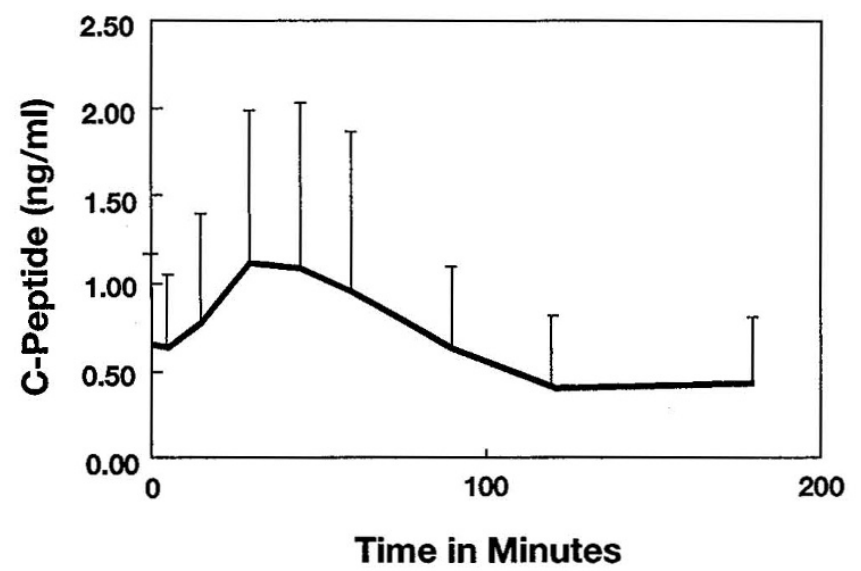

Figure 2. $\mathrm{C}$ Peptide response in $\mathrm{CF}$ patients during meal stimulation test (ng $\cdot \mathrm{ml}^{-1}$ ) (equal to $\left.0.333 \mathrm{nmol} \cdot \mathrm{L}^{-1}\right)(\overline{\mathrm{X}} \pm \mathrm{SD})$.

HGO calculation resulted in a $38 \%$ increase in the CF patients $(p \simeq 0.01)$.

The CF patients seemed to be leaner than the controls although not to a statistically significant extent; percent of body fat was $14 \pm 6 \%$ in the CF patients versus $20 \pm 8 \%$ in controls $(p<0.05)$. However, when expressed as $\mathrm{mg} \cdot \mathrm{kg}$ fat free mass $^{-1} \cdot \min ^{-1}$ (or $\mu \mathrm{mol} \cdot \mathrm{kg}$ fat-free $\operatorname{mass}^{-1} \cdot \min ^{-1}$ ) HGO was $27 \%$ higher in the CF group compared to the controls (4.9 \pm 0.8 versus $3.8 \pm 0.5$ ) (or $27.2 \pm 4.4$ versus $21.1 \pm 2.8)(p$ $=0.015$ ) (Fig. 3). Mean resting energy expenditure $\left(\mathrm{kcal} \cdot \mathrm{kg}^{-1} \cdot \min ^{-1}\right)$ was $29 \%$ higher but not significantly different in the CF patients $(0.036 \pm 0.005)$ compared with the healthy controls $(0.028 \pm 0.013)$. However, when expressed per unit energy expenditure $\left(\mathrm{mg} \cdot \mathrm{kcal}^{-1}\right.$ or $\left.\mu \mathrm{mol} \cdot \mathrm{kcal}^{-1}\right)$, HGO in CF patients $(121 \pm 22$ or $672 \pm 122)$ was not statistically different from the controls $(116 \pm 30$ or $644 \pm$ 167).

As noted above, in seven of the CF patients, the glucose tracer infusion was continued for an additional 120 min during which a continuous infusion of unlabeled glucose also was administered $\left(\overline{\mathrm{X}} \pm \mathrm{SD}, 0.90 \pm 0.02 \mathrm{mg} \cdot \mathrm{kg}^{-1} \cdot \mathrm{min}^{-1}\right.$ or 5.0 $\left.\pm 0.11 \mu \mathrm{mol} \cdot \mathrm{kg}^{-1} \cdot \mathrm{min}^{-1}\right)$. HGO was suppressed by an amount approximately equal $(103 \pm 18 \%)$ to the glucose infusion (Fig. 4 and Table 2). Oral tolbutamide therapy for 2

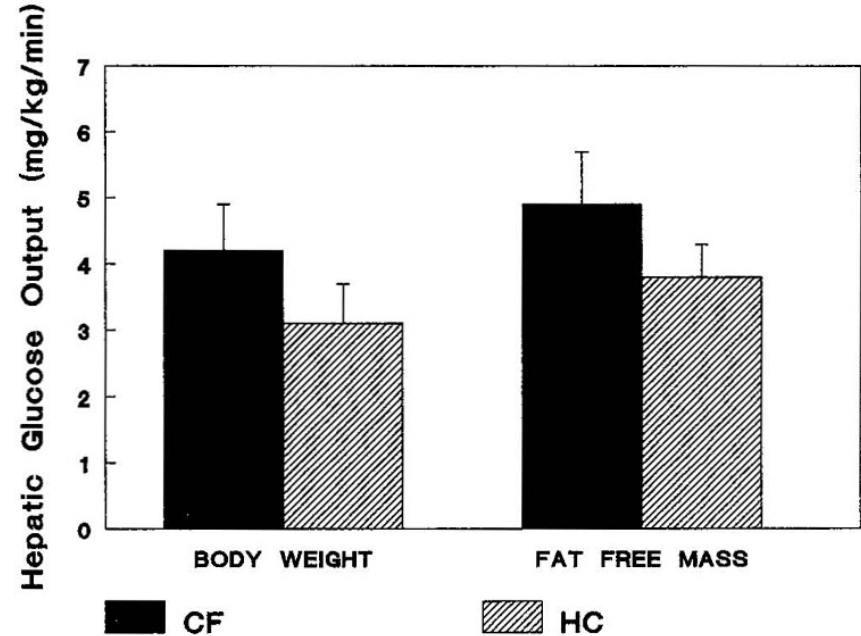

Figure 3. Mean $( \pm \mathrm{SD})$ hepatic glucose output $\left(\mathrm{mg} \cdot \mathrm{kg}^{-1} \cdot \mathrm{min}^{-1}\right)$ (equal to $5.6 \mu \mathrm{mol} \cdot \mathrm{kg}^{-1} \cdot \min ^{-1}$ ) in fasted healthy children $(H C)$ and in children with $\mathrm{CF}(C F)$ in the fasted state. Mean $\pm \mathrm{SD}$ values are presented adjusted for body weight and fat-free mass. Expressed per unit body weight, CF patients $v s$ controls: $p<0.05$; expressed per unit fat-free mass, CF $v s$ controls: $p=0.015$.

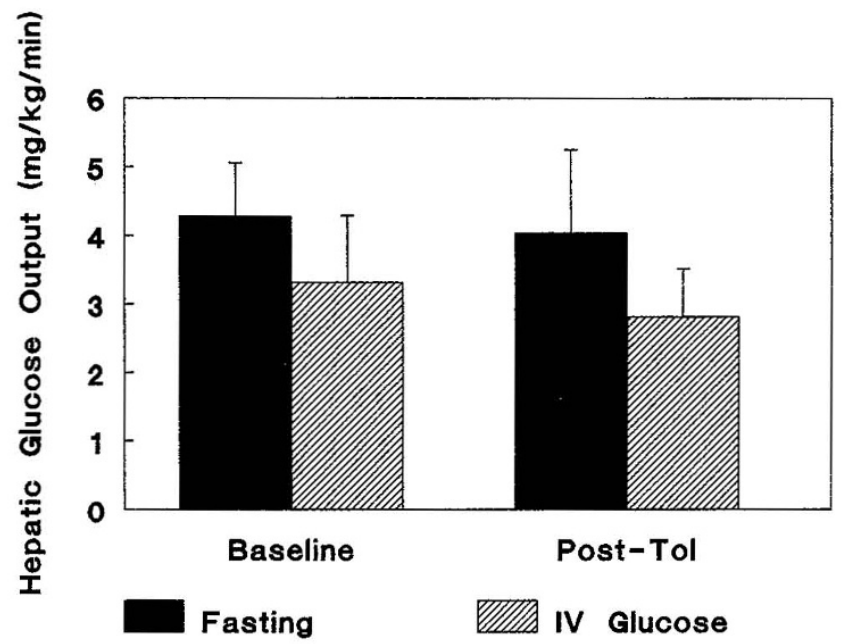

Figure 4. Mean $( \pm \mathrm{SD})$ hepatic glucose output $\left(\mathrm{mg}^{-1} \cdot \mathrm{kg}^{-1} \cdot \mathrm{min}^{-1}\right)$ (equal to $5.6 \mu \mathrm{mol} \cdot \mathrm{kg}^{-1} \cdot \mathrm{min}^{-1}$ ) in patients with cystic fibrosis, in the fasting state and at the end of a two hour infusion of glucose $(\overline{\mathrm{X}} \pm \mathrm{SD}, 0.90 \pm 0.02$ $\mathrm{mg} \cdot \mathrm{kg}^{-1} \cdot \min ^{-1}$ ), both before (baseline) and after (Post-Tol) oral therapy with tolbutamide ( $750 \mathrm{mg} /$ day). Hepatic glucose output was suppressed by an amount approximately equal $(103 \pm 18 \%)$ to the glucose infusion. There were no significant effects of tolbutamide therapy for $2 \mathrm{wk}$ on either the fasting rate of hepatic glucose output or the degree of suppression by glucose.

wk (750 mg/d) (in 5 subjects only) had no effect on either the fasting rate of $\mathrm{HGO}$ or the degree of suppression by glucose (Table 2 and Fig. 4).

\section{DISCUSSION}

As can be seen from Figure 4, oral tolbutamide had no effect on the elevated rate of hepatic glucose production in the fasting state and had no effect on the suppression of hepatic glucose output by glucose infusion. The latter observation is not surprising considering our observation that, even in the baseline condition, a glucose infusion of approximately 1 $\mathrm{mg} \cdot \mathrm{kg}^{-1} \cdot \mathrm{min}^{-1}$ suppressed HGO to an equivalent degree. In view of our earlier observations that tolbutamide therapy 
Table 2. Individual data on $H G O$

\begin{tabular}{cccccc}
\hline & & \multicolumn{4}{c}{$\mathrm{HGO}\left(\mathrm{mg} \cdot \mathrm{kg}^{-1} \cdot \mathrm{min}^{-1}\right)$} \\
\cline { 3 - 6 } $\begin{array}{c}\text { Subject } \\
\text { no. }\end{array}$ & Group & $\begin{array}{c}\text { Fasting } \\
\text { baseline }\end{array}$ & $\begin{array}{c}\text { i.v. } \\
\text { glucose } \\
\text { baseline }\end{array}$ & $\begin{array}{c}\text { Fasting } \\
\text { post-tol }\end{array}$ & $\begin{array}{c}\text { i.v. } \\
\text { glucose } \\
\text { post-tol }\end{array}$ \\
\hline 2029 & CF & 3.7 & 2.6 & 2.4 & 2.0 \\
2012 & CF & 5.0 & 4.3 & & \\
2031 & CF & 5.5 & 4.6 & 3.8 & 2.8 \\
2036 & CF & 3.5 & 2.4 & & \\
2035 & CF & 4.2 & 3.5 & 5.0 & 3.7 \\
2038 & CF & 3.5 & 2.5 & 3.6 & 2.7 \\
2039 & CF & 3.9 & 2.9 & & \\
2041 & CF & 4.5 & & 5.4 & 3.2 \\
$\bar{X} \pm$ SD & & $4.2 \pm 0.7 *$ & $3.3 \pm 9 \dagger$ & $4.0 \pm 1.2 \ddagger$ & $2.9 \pm 0.6 \dagger \ddagger$ \\
2030 & HC & 2.6 & & & \\
2032 & HC & 3.7 & & & \\
2033 & HC & 2.7 & & & \\
2034 & HC & 3.8 & & & \\
2037 & HC & 2.6 & & & \\
$\overline{\mathrm{X}} \pm$ SD & & $3.1 \pm 0.6$ & & & \\
\hline
\end{tabular}

Abbreviations used: HC, healthy controls; post-tol, post tolbutamide therapy.

${ }^{*} p=0.016$ compared to fasted, control.

$\dagger$ Compared to fasting same treatment: baseline, $p<0.0001$; post-tol, $p=$ 0.02 .

$\ddagger p>0.05$ fasting post-tol $v s$ fasting baseline; i.v. glucose post-tol $v s$ i.v. glucose baseline.

seemed to enhance accretion of fat-free mass in children with CF (6), the present results suggest that the putative effect of this drug on growth is not related to its possible inhibitory effects on hepatic gluconeogenesis (25). This view coincides with recent thinking that an accelerated rate of gluconeogenesis does not increase whole body proteolysis in trauma $(26,27)$.

Despite normal clinical tolerance of glucose and normal fasting concentration of glucose, insulin, and C peptide, the CF patients demonstrated higher rates of endogenous glucose production compared with normal children. Because we observed on the basis of the $\mathrm{C}$ peptide concentration, no evidence for decreased insulin secretion in the fasting state, we wondered whether the CF patients were demonstrating hepatic insulin resistance. There is evidence in the literature for both decreased (3) and increased (4) peripheral sensitivity of glucose metabolism to insulin in CF patients, but, to our knowledge, hepatic glucose output has not been studied, at least in prepubertal children with the disease. However insulin/C peptide ratios also were not different in the two groups (implying no difference in hepatic insulin extraction), and the glucose infusion was associated with an equivalent suppression of HGO, suggesting normal hepatic sensitivity to insulin (although glucose not insulin was infused) (9). Thus, there was no evidence for hepatic insulin resistance. Moreover, although we have not formally studied peripheral insulin sensitivity in these patients, it is of interest that insulin to glucose ratios were not different from the healthy control subjects.

Normalizing the HGO data for the fat-free mass did not appreciably reduce the percentage difference observed between CF patients and controls, but if the intensity of energy metabolism per unit cell was greater in the CF patients, then elevated HGO would seem to be an adaptive response to the need for greater glucose uptake. In fact, there is some evidence that interindividual differences in insulin-mediated glucose disposal can best be explained or normalized by using metabolic rate (28). In our study, mean resting energy expenditure was not elevated to a statistically significant degree in the CF patients (despite a $29 \%$ higher rate), but when HGO $(\mathrm{mg} / \mathrm{min}$ ) was normalized for resting energy expenditure $(\mathrm{kcal} / \mathrm{min})$, a difference in HGO between CF patients and controls was no longer identified. Thus, elevated glucose turnover seems to have been the appropriate response to increased glucose, and perhaps energy, needs. Estimation of energy expenditure was based on an assumed respiratory quotient, but this is unlikely to have caused much error in this value (29).

Although our CF patients were afebrile and clinically stable, it is quite plausible that subclinical or incipient inflammation of the lungs also may have contributed to hormonal stress that would lead to elevated HGO. However, counter-regulatory hormone secretion was not assessed in this study; therefore, we are uncertain about the hormonal chain of events that "permitted" HGO to increase above normal and thus, presumably, meet elevated glucose and energy needs.

In summary, glucose tolerant $\mathrm{CF}$ patients, with abnormally diminished insulin secretion in the fed state, demonstrated an increase in fasting, steady-state HGO that was balanced by increased glucose uptake and proportional to an increase in energy expenditure. HGO was apparently normally regulated by exogenous glucose intake (via insulin presumably). Future exploration of the mechanism responsible for the observed increase in HGO might include detailed study of counter regulatory hormone levels and peripheral insulin sensitivity.

Acknowledgments. The authors thank Dr. R. R. Wolfe and his laboratory and the late Kathleen Ault in our laboratory for assistance with the GC/MS analyses; Jon Kepner, Diane Habash, and Anna Sokolov, Ph.D., in our laboratory for technical assistance; Adrienne Petersen, RN, and Cathy Schumer, RN, of the Children's Hospital Clinical Study Center; Susan Jordan, R.D., of the Children's Hospital Dietetics Department; and Brenda Bossetti, R.D., Ph.D., and the nurses of The Ohio State University GCRC for assistance with conducting the clinical aspects of the protocol.

\section{REFERENCES}

1. Lanng S, Thorsteinsson B, Erichsen G, Nerup J, Koch C 1991 Glucose tolerance in cystic fibrosis. Arch Dis Child 66:612-616

2. Handwerger S, Roth J, Gorden P, Di Sant'Agnese P, Carpenter DF, Peter G 1969 Glucose intolerance in cystic fibrosis. N Engl J Med 281:451-461

3. Andersen O, Garne S, Heilmann C, Petersen KE, Petersen W, Koch C 1988 Glucose tolerance and insulin receptor binding to monocytes and erythrocytes in patients with cystic fibrosis. Acta Paediatr Scand 77:67-71

4. Ahmad T, Nelson R, Taylor R 1994 Insulin sensitivity and metabolic clearance rate of insulin in cystic fibrosis. Metabolism 43:163-167

5. Lanng S, Thorsteinsson B, Nerup J, Koch C 1992 Influence of the development of diabetes mellitus on clinical status in patients with cystic fibrosis. Eur J Pediatr 151:684-687

6. Zipf WB, Kien CL, Horswill CA, McCoy KS, O’Dorisio T, Pinyerd BL 1991 Effects of tolbutamide on growth and body composition of nondiabetic children with cystic fibrosis. Pediatr Res 30:309-314

7. Zipf WB, Kien CL, Horswill CA, McCoy KS 1993 Effects of feeding on daily protein turnover balance (DPTB) in cystic fibrosis. FASEB J 7:A178

8. Tanner JM 1962 Growth at Adolescence, 2nd Ed. Blackwell Scientific Publications, Oxford, pp 28-36

9. Wolfe RR, Allsop JR, Burke JF 1979 Glucose metabolism in man: responses to intravenous glucose infusion. Metabolism 28:210-220 
10. Catalano PM, Tyzbir ED, Wolfe RR, Calles J, Roman NM, Amini SB, Sims EAH 1993 Carbohydrate metabolism during pregnancy in control subjects and women with gestational diabetes. Am J Physiol 264:E60-E67

11. Jahoor F, Peters EJ, Wolfe RR 1990 The relationship between gluconeogenic substrate supply and glucose production in humans. Am J Physiol 258:E288-E296

12. Spicher V, Roulet M, Schutz Y 1991 Assessment of total energy expenditure in free-living patients with cystic fibrosis. J Pediatr 118:865-872

13. Grunow JE, Azcue MP, Berall G, Pencharz PB 1993 Energy expenditure in cystic fibrosis during activities of daily living. J Pediatr 122:243-246

14. Tomezsko JL, Stallings VA, Scanlin TF 1989 Resting energy expenditure (REE) in children with cystic fibrosis (CF). Pediatr Res 25:126A (abstr)

15. Vaisman N, Pencharz PB, Corey M, Canny GJ, Hahn E 1987 Energy expenditure of patients with cystic fibrosis. J Pediatr 111:496-500

16. Fried MD, Durie PR, Tsui L-C, Corey M, Levison H, Pencharz PB 1991 The cystic fibrosis gene and resting energy expenditure. J Pediatr 119:913-916

17. Wolfe RR 1992 Radioactive and stable isotope tracers in biomedicine. In: Principles and Practice of Kinetic Analysis. John Wiley \& Sons, New York, pp 425-426

18. Weber JM, Klein S, Wolfe RR 1990 Role of the glucose cycle in control of net glucose flux in exercising humans. J Appl Physiol 68:1815-1819

19. Wong WW, Lee LS, Klein PD 1987 Deuterium and oxygen-18 measurements on microliter samples of urine, plasma, saliva and human milk. Am J Clin Nutr 45:905-913

20. Wong WW, Cochran WJ, Klish WJ, Smith EO'B, Lee LS, Klein PD 1988 In vivo isotope-fractionation factors and the measurement of deuterium- and oxygen-18- dilution spaces from plasma, urine, saliva, respiratory, water vapor, and carbon dioxide. Am J Clin Nutr 47:1-6

21. Schoeller DA, Dietz W, Van Santen E, Klein PD 1982 Validation of saliva sampling for total body water determination by $\mathrm{H}_{2}{ }^{18} \mathrm{O}$ dilution. Am J Clin Nutr 35:591-594

22. Boileau RA, Lohman TG, Slaughter MH, Ball TE, Going SB, Hendrix MK 1984 Hydration of the fat-free body in children during maturation. Hum Biol 56:651-666

23. Black AE, Prentice AM, Coward WA 1986 Use of food quotients to predic respiratory quotients for the doubly-labeled water method of measuring energy expenditure. Hum Nutr Clin Nutr 40C:381-391

24. Osei K, Holland GC 1987 Altered C-peptide/insulin molar ratios and glucose turnove rates after stimulation in nondiabetic offsprings of type II diabetic patients. Metabolism 36:122-127

25. Cabeilo MA, Rodriguez-Tarduchy G, Ortega JL, Samper B, Feliu JE 1991 Inhibition of gluconeogenesis by tolbutamide in isolated rat hepatocytes: modulation of glucose6-phosphate substrate cycle. Metabolism 9:934-940

26. Jahoor F, Shangraw RE, Miyoshi H, Wallish H, Herndon DN, Wolfe RR 1989 Role of insulin and glucose oxidation in mediating the protein catabolism of burns and sepsis. Am J Physiol 257:E323-E331

27. Wolfe RR, Jahoor F, Hartl WH 1989 Protein and amino acid metabolism after injury. Diabetes Metab Rev 5:149-164

28. Lillioja S, Bogardus C 1988 Obesity and insulin resistance: lessons learned from the Pima indians. Diabetes Metab Rev 4:517-540

29. Elia M 1991 Energy equivalents of $\mathrm{CO}_{2}$ and their importance in assessing energy expenditure when using tracer techniques. Am J Physiol 260:E75-E88 